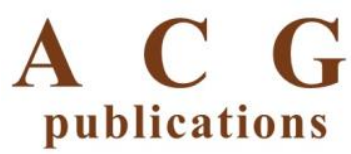

Rec. Nat. Prod. 13:6 (2019) 456-461

records of natural

products

\title{
A New Heliquinomycin Analogue with Immunosuppressive Activity from Streptomyces sp. jys28
}

\section{Can Su 1,2, Chongxi Liu ${ }^{3}$, Yongjiang Wang ${ }^{2}$, Wen-Sheng Xiang 3 , Chenggang Zou ${ }^{* 1}$ and Sheng-Xiong Huang $* 2$}

\author{
${ }^{1}$ State Key Laboratory for Conservation and Utilization of Bio-Resources in Yunnan, School of Life \\ Sciences, Yunnan University, Kunming, 650091, China \\ ${ }^{2}$ State Key Laboratory of Phytochemistry and Plant Resources in West China, CAS Center for \\ Excellence in Molecular Plant Sciences, Kunming Institute of Botany, Chinese Academy of Sciences, \\ Kunming 650204, China. \\ ${ }^{3}$ Life Science and Biotechnology Research Center, School of Life Science, Northeast \\ Agricultural University, Harbin 150030, China
}

(Received December 03, 2018; Revised March 17, 2019; Accepted March 18, 2019)

\begin{abstract}
Heliquinomycin (1) and a new analogue 9'-methoxy-heliquinomycin (2) were isolated from the culture broth of Streptomyces sp. jys28. The structure of new analogue was elucidated by comprehensive analyses of HR-ESI-MS and NMR spectroscopic data. Among them, Heliquinomycin (1) showed immunosuppressive and antibacterial activities.
\end{abstract}

Keywords: Heliquinomycin; immunosuppressive activity; antibacterial activity. (C) 2019 ACG Publications. All rights reserved.

\section{Introduction}

Rubromycins are a family of structurally related compounds isolated from Actinomycetes [1]. They exhibit an attractive array of biological activity, such as antimicrobial [2,3], cytotoxicity [4], enzyme inhibition [5,6], and telomerase inhibition [5,7]. Heliquinomycin, a member of rubromycin family containing a rare deoxycymarose, has been reported from Streptomyces sp. MJ929-SF2 with selective inhibition of DNA helicase $[3,8,9]$. During our continuous efforts to discover new or bioactive natural products from characteristic actinomycetes (mainly Streptomyces) [10-13], Streptomyces sp. jys28, which can produce secondary metabolites with distinctive UV absorptions, attracted our attention. Strain Streptomyces sp. jys 28 was isolated from the rhizoshere soil of Pinus yunnanensis, which was collected from the surrounding area of Fuxian lake, Yunnan Province, China. Two compounds, heliquinomycin (1) and its new analogue (2), were isolated from the culture broth of Streptomyces sp. jys28. In this paper, we describe the isolation, structural elucidation, immunosuppressive and antimicrobial activities of compounds $\mathbf{1}$ and $\mathbf{2}$.

*Corresponding authors: E-Mail: chgzou@ynu.edu.cn (C.G. Zou); Phone: 086-871-65034838 Fax: 086-87165034838; sxhuang@mail.kib.ac.cn (S.-X. Huang); Phone:086-871-65215112 Fax: 086-871-65215112 


\section{Materials and Methods}

\subsection{General}

Optical rotation was detected using a JASCO P-1020 digital Polarimeter. UV spectrum was measured using Shimadzu UV-2401PC UV-VIS spectrophotometer. IR spectrum was measured in $\mathrm{KBr}$ discs using a Bruker Tensor 27 FTIR Spectrometer. 1D and 2D NMR spectra were measured in $\mathrm{CDCl}_{3}$ on a Bruker AVANCE III-600 spectrometer with TMS as an internal standard. The ESI-MS and HR-ESI-MS were taken using a UPLC-IT-TOF mass spectrometer (Shimadzu Biotech, Kyoto, Japan). Column chromatography (CC) was performed on silica gel (200-300 mesh, Qingdao Marine Chemical Inc.) or Sephadex LH-20 (25-100 $\mu \mathrm{m}$, Pharmacia Biotech Ltd.). Semipreparative HPLC was conducted on a HITACHI Chromaster system equipped with a DAD detector, a YMC-Triart $\mathrm{C}_{18}$ column $(250 \mathrm{~mm} \times 10 \mathrm{~mm}$ i.d., $5 \mu \mathrm{m}$, YMC Corp.), at a flow rate of $3.0 \mathrm{~mL} / \mathrm{min}$ and a column temperature of $25^{\circ} \mathrm{C}$.

\subsection{Isolation of Streptomyces sp. jys 28 and the Cultivation}

The strain Streptomyces sp. jys28 was isolated from the rhizosphere soil of Pinus yunnanensis. It was identified as one species of the genus Streptomyces based on 16S rRNA gene sequence analysis (GenBank No. SUB4300555). This strain was maintained on oatmeal agar plates (Oat $20 \mathrm{~g}, \mathrm{KNO}_{3} 0.2$ $\mathrm{g}, \mathrm{MgSO}_{4} 0.2 \mathrm{~g}, \mathrm{~K}_{2} \mathrm{HPO}_{4} 0.5 \mathrm{~g}$ and agar $20 \mathrm{~g}$ in $1 \mathrm{~L}$ of water) for $6 \mathrm{~d}$ at $30{ }^{\circ} \mathrm{C}$. Then, it was inoculated into $250 \mathrm{~mL}$ baffle Erlenmeyer flasks containing $50 \mathrm{~mL}$ of sterile seed medium (Tryptone soy broth, $30 \mathrm{~g} / \mathrm{L}$ ) and cultivated for 2 days on a rotary shaker at $200 \mathrm{rpm}$ and $30^{\circ} \mathrm{C} .25 \mathrm{~L}$ production medium ( $20 \mathrm{~g}$ glucose, $10 \mathrm{~g}$ malt extract, $5 \mathrm{~g}$ yeast extract in $1 \mathrm{~L}$ of water, $\mathrm{pH}$ 7.2) was transferred into $1 \mathrm{~L}$ Erlenmeyer flasks, each with $250 \mathrm{~mL}$. After sterilized, the seed broth was transferred into production medium at $5 \%$ inoculation proportion. After cultured on a rotary shaker at $200 \mathrm{rpm}$ and $30{ }^{\circ} \mathrm{C}$ for $7 \mathrm{~d}$, the production medium was collected for later use.

\subsection{Extraction and Isolation}

The production medium was separated by centrifugation and filtration. The supernatant was extracted three times using an equal volume of EtOAc. The combined EtOAc phase was concentrated on a rotary evaporator to yield the crude extract. This extract was subjected to a 200-300 mesh silica gel column chromatography using a gradient petroleum ether/ EtOAc solvent system (1:0, 20:1, 10:1, $3: 1,1: 1,1: 3,1: 10,0: 1)$ to afford eight fractions. Fraction of petroleum ether/ EtOAc phase 1:3 (1.02 g) was then separated by Sephadex LH-20 column $\left(\mathrm{MeOH}-\mathrm{CHCl}_{3}, 1: 1\right)$ to give four subfractions. The second subfraction was further separated by semipreparative HPLC eluting with $\mathrm{CH}_{3} \mathrm{CN} / \mathrm{H}_{2} \mathrm{O}$ (57:43, $\mathrm{v} / \mathrm{v})$ to afford compounds $\mathbf{1}\left(20.5 \mathrm{mg}, t_{\mathrm{R}}=12.9 \mathrm{~min}\right)$ and $\mathbf{2}\left(2.1 \mathrm{mg}, t_{\mathrm{R}}=10.6 \mathrm{~min}\right)$.

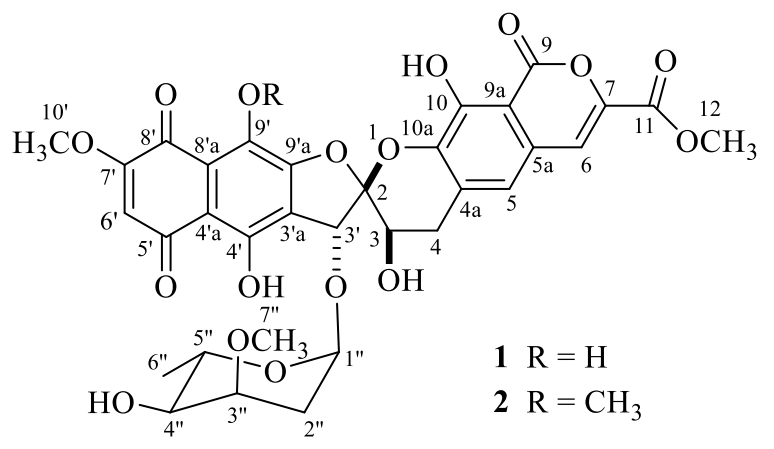

Figure 1. Structure of compounds 1 and 2 
A new heliquinomycin analogue

\subsection{Immunosuppressive Activity Test}

Immunosuppressive activity test was constructed according to the reported protocol [14]. The T cells were isolated from PBMCs of healthy donors. Plate-bound anti-CD3 and soluble anti-CD28 were used to activate the naive $\mathrm{T}$ cells. Subsequently, they were incubated with or without different concentrations of the tested compounds for $72 \mathrm{~h}$. The proliferation of the T cells was measured by flow cytometry. The negative control was the cells without stimulation or drug, and the cells with the stimulation but without the drug was the positive control. Cell viability assay was performed as follows: human naive $\mathrm{T}$ cells were treated with different concentrations of the tested compounds or vehicle for $72 \mathrm{~h}$. The viability of cells were assessed using the CCK-8 assay kit though the OD values at $450 \mathrm{~nm}$ in a SpectraMax M5 microplate reader (Molecular Devices, Sunnyvale,CA, USA).

GraphPad Prism 6 (Graph Pad, San Diego, CA, USA) was used to calculate 50\% inhibitory concentrations $\left(\mathrm{IC}_{50}\right)$ for $\mathrm{T}$ cell proliferation and $50 \%$ cytotoxic concentration $\left(\mathrm{CC}_{50}\right)$ of the tested compounds.

\subsection{Antibacterial Activity Test}

Tested strains were Escherichia coli ATCC 8099, Bacillus subtilis ATCC 6633, and Staphylococcus aureus ATCC 6538. Minimum inhibitory concentration (MIC) was tested using 96well plate microdilution method [12]. $160 \mu \mathrm{L}$ of the LB medium was dispensed in the first well, while the other wells were dispensed $100 \mu \mathrm{L}$ of LB medium. $10 \mu \mathrm{L}$ of $20 \mathrm{mg} / \mathrm{mL}$ of the tested compounds dissolved in dimethyl sulfoxide (DMSO) and $30 \mu \mathrm{L}$ of sterile water were dispensed in the first well and mixed with a micropipette, then $100 \mu \mathrm{L}$ of this dilution was transferred to next well to yield twofold serial dilution. This process was repeated twenty-three times and $100 \mu \mathrm{L}$ of mixed liquid in the last well was discarded, finally resulting in twenty-four concentrations of the tested compounds. For the positive control kanamycin, $40 \mu \mathrm{L}$ of $5 \mathrm{mg} / \mathrm{mL}$ of kanamycin dissolved in water was dispensed in the first well, and then was also serially diluted as the tested compounds. 25\% DMSO aqueous solution was the negative sample. $100 \mu \mathrm{L}$ of tested strain (an $\mathrm{OD}_{600}$ of 0.02 ) was dispensed to each of the wells included the positive and negative control. The microplates were incubated at $37^{\circ} \mathrm{C}$ for 16 hours. After the incubation, bacterial growth was observed by the naked eye, and the lowest concentration at which the medium was clear was taken as the MIC value.

\section{Results and Discussion}

\subsection{Structure Elucidation}

Compound 1 was isolated as a red powder, its ESI-MS spectrum showed a molecular ion peak at $m / z 697[\mathrm{M}-\mathrm{H}]^{-} \cdot{ }^{1} \mathrm{H}$ and ${ }^{13} \mathrm{C}$ NMR spectroscopic data of compound 1 were summarized in Table 1. Compound 1 was proved to be heliquinomycin by direct comparison of these data with those from the literature [8].

Compound 2, $[\alpha]_{\mathrm{D}}^{25}+24.36\left(c 0.34, \mathrm{CHCl}_{3}\right), \mathrm{UV}\left(\mathrm{CHCl}_{3}\right) \lambda_{\max } \mathrm{nm}(\log \varepsilon): 455.5(3.59), 363.0$ (3.89), 350.5 (3.92), 311.0 (4.15) and 242 (4.37), was isolated as a saffron yellow powder. Its ESI-MS spectrum showed a pseudo-molecular ion peak at $\mathrm{m} / \mathrm{z} 711[\mathrm{M}-\mathrm{H}]^{-}$and molecular formula was determined as $\mathrm{C}_{34} \mathrm{H}_{32} \mathrm{O}_{17}$ by HRESI-MS at $m / z 711.1567[\mathrm{M}-\mathrm{H}]^{-}$(calcd for $\mathrm{C}_{34} \mathrm{H}_{32} \mathrm{O}_{17}, 711.1564$ ). The IR spectrum of 2 showed characteristic absorption bands of hydroxyl and ketone groups at 3446 and $1726 \mathrm{~cm}^{-1}$, respectively. The NMR data of 2 were similar to those of $\mathbf{1}$, except for the presence of an additional methoxy group signal at $\delta_{\mathrm{H}} 3.77$ and $\delta_{\mathrm{C}} 61.3$ (Table 1) in 1. The HMBC spectrum of 2 showed long-range correlations between $9^{\prime}-\mathrm{OCH}_{3}$ and $\mathrm{C}-9$ ', which suggested that $\mathrm{C}-9$ ' of $\mathbf{2}$ was connected with a methoxy group. The NMR data of $\mathbf{2}$ showed that it contains a cymarose as $\mathbf{1}$. The ${ }^{1} \mathrm{H}$ NMR peak of cymarose moiety in the $\mathrm{CDCl}_{3}$ solvent is not splitted well. We then measured the ${ }^{1} \mathrm{H}$ NMR in pyridine- $d_{5}$ solvent. From the ${ }^{1} \mathrm{H}$ NMR in pyridine- $d_{5}$, we got the $J$ value of $\mathrm{H}-1$ " is $3.7 \mathrm{~Hz}$. In the ROESY spectrum, significant cross peaks between $\mathrm{H}-2^{\prime \prime} / \mathrm{H}-4^{\prime \prime}$ and $\mathrm{H}-4{ }^{\prime \prime} / \mathrm{H}-6^{\prime \prime}$ were observed. 
From the above all analyses, it can be indicated that the relative configuration of the cymarose in the $\mathbf{2}$ was the same as in the heliquinomycin. Thus, the structure of $\mathbf{2}$ was identified as shown in Figure 1, and named 9'-methoxy-heliquinomycin.

Table 1. ${ }^{1} \mathrm{H}(600 \mathrm{MHz})$ and ${ }^{13} \mathrm{C}$ NMR $(150 \mathrm{MHz})$ data of compounds $\mathbf{1}$ and $\mathbf{2}$ in $\mathrm{CDCl}_{3}$

\begin{tabular}{|c|c|c|c|c|}
\hline \multirow{2}{*}{ Position } & \multicolumn{2}{|r|}{1} & \multicolumn{2}{|r|}{2} \\
\hline & $\delta \mathrm{c}(\mathrm{ppm})$ & $\delta_{\mathrm{H}}(\mathrm{ppm}, J$ in $\mathrm{Hz})$ & $\delta \mathrm{c}(\mathrm{ppm})$ & $\delta_{\mathrm{H}}(\mathrm{ppm}, J$ in $\mathrm{Hz})$ \\
\hline $2,2^{\prime}$ & 112.1 & & 111.6 & \\
\hline \multirow[t]{2}{*}{3} & 61.7 & $4.55(1 \mathrm{H}, \mathrm{s}, \mathrm{H}-3)$ & 61.8 & $4.54(1 \mathrm{H}$, br s $)$ \\
\hline & & $5.34(1 \mathrm{H}, \mathrm{br} \mathrm{s})(3-\mathrm{OH})$ & & $5.31(1 \mathrm{H}$, br s $)(3-\mathrm{OH})$ \\
\hline \multirow[t]{2}{*}{4} & 30.4 & $3.08(1 \mathrm{H}$, br d, $J=16.8)$ & 30.4 & $3.10(1 \mathrm{H}, \mathrm{dd}, J=17.0,1.8)$ \\
\hline & & $3.55(1 \mathrm{H}$, br d, $J=16.8)$ & & $3.50(1 \mathrm{H}, \mathrm{dd}, J=17.0,3.3)$ \\
\hline $4 a$ & 130.4 & & 130.3 & \\
\hline 5 & 119.2 & $6.95(1 \mathrm{H}, \mathrm{s})$ & 119.1 & $6.96(1 \mathrm{H}, \mathrm{s})$ \\
\hline $5 \mathrm{a}$ & 128.1 & & 128.0 & \\
\hline 6 & 113.8 & $7.43(1 \mathrm{H}, \mathrm{s})$ & 113.7 & $7.44(1 \mathrm{H}, \mathrm{s})$ \\
\hline 7 & 141.4 & & 141.3 & \\
\hline 9 & 165.2 & & 165.1 & \\
\hline $9 \mathrm{a}$ & 106.9 & & 106.9 & \\
\hline 10 & 150.4 & & 150.4 & \\
\hline $10-\mathrm{OH}$ & & $11.00(1 \mathrm{H}, \mathrm{s})$ & & $11.00(1 \mathrm{H}, \mathrm{s})$ \\
\hline $10 \mathrm{a}$ & 140.7 & & 140.7 & \\
\hline 11 & 160.7 & & 160.7 & \\
\hline 12 & 53.2 & $3.94(3 \mathrm{H}, \mathrm{s})$ & 53.1 & $3.95(3 \mathrm{H}, \mathrm{s})$ \\
\hline 3' & 76.9 & $5.80(1 \mathrm{H}, \mathrm{s})$ & 76.8 & $5.82(1 \mathrm{H}, \mathrm{s})$ \\
\hline 3'a & 123.0 & & 120.7 & \\
\hline 4' & 160.1 & & 157.2 & \\
\hline 4'-OH & & $13.54(1 \mathrm{H}, \mathrm{s})$ & & $13.68(1 \mathrm{H}, \mathrm{s})$ \\
\hline 4'a & 106.8 & & 109.8 & \\
\hline $5^{\prime}$ & 183.8 & & 189.9 & \\
\hline 6 & 110.6 & $6.20(1 \mathrm{H}, \mathrm{s})$ & 108.4 & $6.02(1 \mathrm{H}, \mathrm{s})$ \\
\hline $7^{\prime}$ & 160.0 & & 161.1 & \\
\hline $8^{\prime}$ & 179.3 & & 178.1 & \\
\hline $8^{\prime} \mathrm{a}$ & 114.2 & & 124.6 & \\
\hline $9^{\prime}$ & 150.6 & & 141.0 & \\
\hline 9'-OH & & $12.13(1 \mathrm{H}, \mathrm{s})$ & & \\
\hline 9'a & 156.2 & & 159.1 & \\
\hline $10^{\prime}$ & 57.0 & $3.94(3 \mathrm{H}, \mathrm{s})$ & 56.9 & $3.88(3 \mathrm{H}, \mathrm{s})$ \\
\hline $9^{\prime}-\mathrm{OCH}_{3}$ & & & 61.3 & $3.77(3 \mathrm{H}, \mathrm{s})$ \\
\hline $1 "$ & 94.3 & $5.57(1 \mathrm{H}, \mathrm{s})$ & 94.3 & $5.59(1 \mathrm{H}$, br s $)$ \\
\hline & & & & $5.92(1 \mathrm{H}, \mathrm{dd}, J=3.7)^{\mathrm{a}}$ \\
\hline $2 "$ & 31.0 & $1.87(1 \mathrm{H}$, br d, $J=15.0)$ & 30.9 & $1.87(1 \mathrm{H}$, br d, $J=15.0)$ \\
\hline & & $2.32(1 \mathrm{H}$, br $\mathrm{d}, J=15.0)$ & & $2.32(1 \mathrm{H}$, br d, $J=15.0)$ \\
\hline 3" & 76.5 & $3.70(1 \mathrm{H}$, br s $)$ & 76.5 & $3.70(1 \mathrm{H}$, br d, $J=2.6)$ \\
\hline $4 "$ & 71.9 & $3.33(1 \mathrm{H}$, br s $)$, & 71.8 & $3.34(1 \mathrm{H}$, br s $)$ \\
\hline 4"-OH & & $2.06(1 \mathrm{H}$, br s $)$ & & $2.20(1 \mathrm{H}$, br s $)$ \\
\hline $5^{\prime \prime}$ & 66.0 & $3.93(1 \mathrm{H}, \mathrm{dd}, J=9.3,6.0)$ & 66.0 & $3.92(1 \mathrm{H}, \mathrm{dd}, J=9.3,6.0)$ \\
\hline $6 "$ & 18.4 & $1.40(3 \mathrm{H}, \mathrm{d}, J=6.0)$ & 18.3 & $1.41(3 \mathrm{H}, \mathrm{d}, J=6.0)$ \\
\hline 7" & 57.6 & $3.50(3 \mathrm{H}, \mathrm{s})$ & 57.5 & $3.51(3 \mathrm{H}, \mathrm{s})$ \\
\hline
\end{tabular}

${ }^{\mathrm{a} 1} \mathrm{H}(600 \mathrm{MHz}) \mathrm{NMR}$ for compound 2 in pyridine- $d_{5}$. 


\subsection{Immunosuppressive and Antibacterial Activities}

Immunosuppressive activity of the two isolates were evaluated. Compound $\mathbf{1}$ showed inhibition against $\mathrm{T}$ cell proliferation with $\mathrm{IC}_{50}$ value of $7.8 \mu \mathrm{M}$ and low cytotoxicity with $\mathrm{CC}_{50}$ value of 65.7 $\mu \mathrm{M}$, implying that compound $\mathbf{1}$ inhibited $\mathrm{T}$ cell proliferation through immunosuppressive activity, but not cytotoxicity. The inhibitory activities of the two isolates were also tested in vitro against E. coli, B.subtilis, and S. aureus. The results (Table 2) showed that compound $\mathbf{1}$ had potent antibacterial activity.

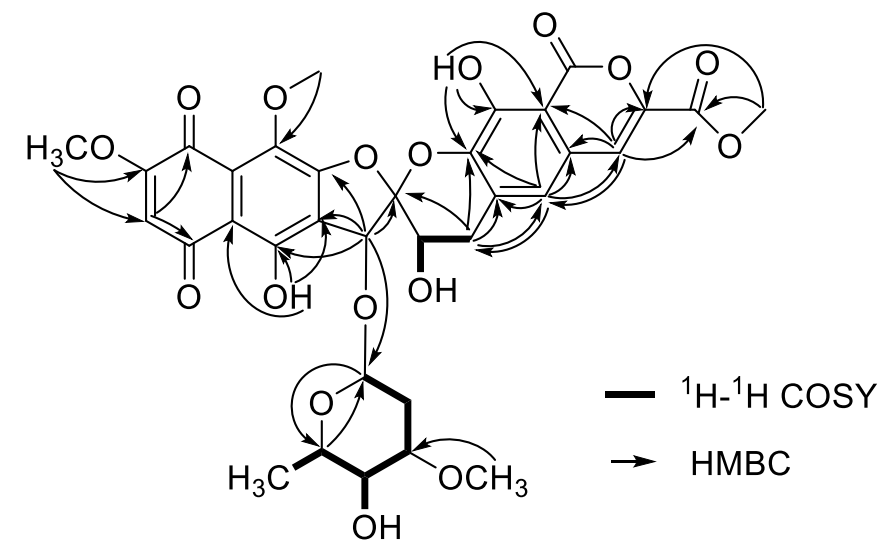

Figure 2. Key ${ }^{1} \mathrm{H}-{ }^{1} \mathrm{H}$ COSY and HMBC correlations of compound 2

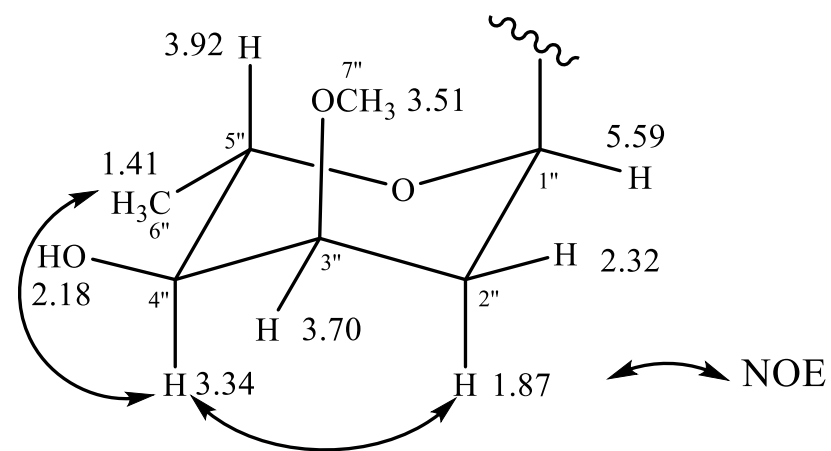

Figure 3. Key ROESY correlations for stereochemistry assignment of the sugar moiety showing the carbon numbering and ${ }^{1} \mathrm{H}$ NMR chemical shift

Table 2. MIC of compounds 1 and $2(\mu \mathrm{g} / \mathrm{mL})$

\begin{tabular}{lllc}
\hline Test bacterial & $\mathbf{1}$ & $\mathbf{2}$ & Kanamycin \\
\hline E. coli & 0.49 & 7.81 & 7.81 \\
B. subtilis & 0.12 & 62.50 & 0.49 \\
S. aureus & 0.49 & 15.63 & 7.81 \\
\hline
\end{tabular}

\section{Acknowledgments}

This work was financially supported by the National Natural Science Foundation of China, (No. U1702285 and 21402214), the Applied Basic Research Foundation of Yunnan Province (No. 2013HA022), and the Key Research Program of Frontier Sciences, CAS (No. QYZDB-SSWSMC051).

\section{Supporting Information}

Supporting information accompanies this paper on http://www.acgpubs.org/journal/records-ofnatural-products 


\section{ORCID}

Can Su: 0000-0002-6031-3581

Chongxi Liu: 0000-0002-6505-7820

Yongjiang Wang: 0000-0003-2155-5577

Wen-Sheng Xiang: 0000-0002-1826-5985

Chenggang Zou: 0000-0001-5519-4402

Sheng-Xiong Huang: 0000-0002-3616-8556

\section{References}

[1] D. J. Atkinson and M. A. Brimble (2015). Isolation, biological activity, biosynthesis and synthetic studies towards the rubromycin family of natural products, Nat. Prod. Rep. 32, 811-840.

[2] A. Trani, C. Dallanoce, G. Panzone, F. Ripamonti, B. P. Goldstein and R. Ciabatti (1997). Semisynthetic derivatives of purpuromycin as potential topical agents for vaginal infections, J. Med. Chem. 40, 967-971.

[3] M. Chino, K. Nishikawa, M. Umekita, C. Hayashi, T. Yamazaki, T. Tsuchida, T. Sawa, M. Hamada and T. Takeuchi (1996). Heliquinomycin, a new inhibitor of DNA helicase, produced by Streptomyces sp. MJ929-SF2 I. Taxonomy, production, isolation, physico-chemical properties and biological activities, $J$. Antibiot. 49, 752-757.

[4] M. Chino, K. Nishikawa, A. Yamada, M. Ohsono, T. Sawa, F. Hanaoka, M. Ishizuka and T. Takeuchi (1998). Effect of a novel antibiotic, heliquinomycin, on DNA helicase and cell growth, J. Antibiot. 51, 480-486.

[5] T. Ueno, H. Takahashi, M. Oda, M. Mizunuma, A. Yokoyama, Y. Goto, Y. Mizushina, K. Sakaguchi and H. Hayashi (2000). Inhibition of human telomerase by rubromycins: implication of spiroketal system of the compounds as an active moiety, Biochemistry 39, 5995-6002.

[6] M. E. Goldman, G. S. Salituro, J. A. Bowen, J. M. Williamson, D. L. Zink, W. A. Schleif and E. A. Emini (1990). Inhibition of human immunodeficiency virus-1 reverse transcriptase activity by rubromycins: competitive interaction at the template primer site, Mol. Pharmacol. 38, 20-25.

[7] Y. Mizushina, T. Takeuchi, F. Sugawara and H. Yoshida (2012). Anti-cancer targeting telomerase inhibitors: beta-rubromycin and oleic acid, Mini. Rev. Med. Chem. 12, 1135-1143.

[8] M. Chino, K. Nishikawa, T. Tsuchida, R. Sawa, H. Nakamura, K. T. Nakamura, Y. Muraoka, D. Ikeda, H. Naganawa, T. Sawa and T. Takeuchi (1997). Heliquinomycin, a new inhibitor of DNA helicase, produced by Streptomyces sp. MJ929-SF2 II. Structure determination of heliquinomycin, J. Antibiot. 50, 143-146.

[9] T. Sugiyama, M. Chino, T. Tsurimoto, N. Nozaki and Y. Ishimi (2012). Interaction of heliquinomycin with single-stranded DNA inhibits MCM4/6/7 helicase, J. Biochem. 151, 129-137.

[10] Z. Yu, L. Wang, J. Yang, F. Zhang, Y. Sun, M. Yu, Y. Yan, Y. T. Ma and S. X. Huang (2016). A new antifungal macrolide from Streptomyces sp. KIB-H869 and structure revision of halichomycin, Tetrahedron Lett. 57, 1375-1378.

[11] R. Yang, J. Yang, L. Wang, J. P. Huang, Z. Xiong, J. Luo, M. Yu, Y. Yan and S. X. Huang (2017). Lorneic acid analogues from an endophytic actinomycete, J. Nat. Prod. 80, 2615-2619.

[12] M. Elshikh, S. Ahmed, S. Funston, P. Dunlop, M. McGaw, R. Marchant, I. M. Banat (2016). Resazurinbased 96-well plate microdilution method for the determination of minimum inhibitory concentration of biosurfactants, Biotechnol. Lett. 38, 1015-1019.

[13] Z. Xiong, J. Huang, Y. Yan, L. Wang, Z. Wang, J. Yang, J. Luo, J. Li and S. X. Huang (2018). Isolation and biosynthesis of labdanmycins: four new labdane diterpenes from endophytic Streptomyces, Org. Chem. Front. 5. 1272-1279

[14] T. Zeng, X. Wu, S. Yang, W. Lai, S. Shi, Q. Zou, Y. Liu and L. Li (2017). Monoterpenoid indole alkaloids from Kopsia officinalis and the immunosuppressive activity of Rhazinilam, J. Nat. Prod. 80, 864-871.

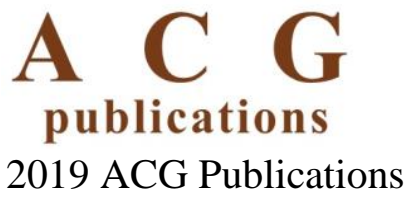

